$\xi=-1$

\title{
Soil Invertebrate Animals as Indicators of Contamination of Light Chestnut Ground of Southeast of Kazakhstan
}

\author{
Tukenova Zulfia ${ }^{1}$, Alimzhanova Mereke ${ }^{1,2,4^{*}}$, Kazybaeyeva Saule ${ }^{1,3}$, Ashimuly Kazhybek ${ }^{1,4}$, Zhylkybaev Oral ${ }^{1,2,5}$ \\ ${ }^{I}$ Kazakhstan Engineering and Technological University, Almaty, Kazakhstan \\ ${ }^{2}$ Faculty of Chemistry and Chemical Technology, Al-Farabi Kazakh National University, Almaty, Kazakhstan \\ ${ }^{3}$ Research Institute of Horticulture and Viticulture, Almaty, Republic of Kazakhstan \\ ${ }^{4}$ LTD Scientific-Production Center of Microbiology and Virology \\ ${ }^{5}$ LTDAspan Tau, Almaty, Kazakhstan \\ *Corresponding Author: (Phone: +77014411299; Email: mereke.84@mail.ru)
}

\begin{abstract}
The use of living organisms as biological indicators for environmental change necessitates the development of a number of criteria on the basis of which it is possible to select indicator species. These include the biological activity of soils (mesofauna, enzymes). Bioindicators with a chronic anthropogenic load on the soil, in particular with prolonged application of fertilizers, can react to very weak effects due to dose accumulation, in addition, they make it unnecessary to use expensive and laborious physical and chemical methods for measuring biological parameters. The novelty of our research is based on the study of the influence of anthropogenic influences on the biological activity of soils in comparison with its basic indicators. This will allow us to establish a correlation between the soil fauna and the main traditional indicators of soil fertility, and significantly enhance their ecological significance in assessing agricultural practices in agricultural production. It has been revealed that the soils under study differ in relatively favorable physical properties, which in turn affects the distribution of the mesofauna. When the biological activity of soils was diagnosed, a decrease in the activity of soil mesofauna was noted in variants with high doses of phosphorus fertilizers depending on the type of soil. In light chestnut soils, meso-faunistic indices are reduced to $\left(16 \mathrm{ind} \cdot \mathrm{m}^{-2}\right)$ and poor group diversity. The main representatives of the soil mesofauna are Carabidae, Formicidae, Lumbricidae, Scarabeidae. Typical species for fertilized soils are Carabidae, Lumbricidae, Scarabeidae. It was revealed that larvae of the mesofauna of soils from the family Curculionidae, Scarabaeidae are characteristic representatives. Representatives of these families can be used as bioindicators in conducting studies on the investigated soils. Bioindicator species of the investigated soils are present irrespective of the use of mineral fertilizers and, accordingly, the level of pesticide content.
\end{abstract}

Keywords: agrochemical indicators, bioindicators, light chestnut, mesofauna, soil

\section{Introduction}

Preservation and improvement of soil fertility is impossible without the introduction of organic and mineral fertilizers in conjunction with observance of crop rotations, soil cultivation systems, the use of new adapted varieties, land reclamation measures. Obtaining information about the environment is possible either with the help of chemical methods or on the basis of an assessment of the state of biological objects - bioindication. Bioindication methods determine the presence of a pollutant in the environment by the presence or condition of certain organisms that are most sensitive to changes in the ecological situation.

The use of living organisms as biological indicators for environmental change necessitates the development of a number of criteria on the basis of which it is possible to select indicator species. These include the biological activity of soils (mesofauna, enzymes). Bioindicators with a chronic anthropogenic load on the soil, in particular with prolonged application of fertilizers, can react to very weak effects due to dose accumulation, in addition, they make it unnecessary to use expensive and laborious physical and chemical methods for measuring biological parameters. In this connection, the study and identification of soil bioindicators for agrocenoses of the southeast of the republic at various levels of application of mineral fertilizers becomes urgent [1-5]. The research objectives included: Identify species, soil invertebrate animals that are indicators of soil contamination with pesticides and high fertilizer rates. To study the effect of pesticides and fertilizers on biological activity, humus status, soil content of forms of nitrogen, phosphorus, potassium and trace elements accessible to plants for the use of these indicators in the monitoring of anthropogenic impacts. The novelty of our research is based on the study of the influence of anthropogenic influences on the biological activity of soils in comparison with its basic indicators, which will allow us to establish a correlation between the soil fauna and the main traditional indicators of soil fertility, and significantly enhance their ecological significance in assessing agricultural practices in agricultural production. As studies of recent years show, fertilizers and plant protection products have a negative effect on soil biota. The use of pesticides can lead to the restructuring of the ecological situation in the soil, changing its biocenosis - inhibiting certain groups of soil groups and stimulating the reproduction of others, whose representatives are able to produce phytotoxic substances and thereby aggravate the negative effect of the drugs used. The lack of information about the biological activity in this zone, the underestimation of the role of soil invertebrates and their 
significance in the formation and reproduction of soil fertility, the lack of bioiodiagnostic methods and soil indications of agrotechnical methods, determined the urgency and necessity of carrying out systematic studies in this direction. The foregoing served as the basis for choosing the topic and direction of the study on the effect of various systems of application of mineral fertilizers, pesticides and other agro-technical methods on the living component of the soil environment in long-term stationary experiments, and on their basis the development of parameters for monitoring anthropogenic impacts in the system of modern agriculture in the irrigation zone and the south of the south -the east of Kazakhstan. Over the past few decades, more and more attention has been paid to the residual analysis of pesticides in the environment and biological objects. Similar and related alternative research in Kazakhstan is not carried out. Data on the development of physic - chemical and biological basis for monitoring the anthropogenic impacts in the system of modern agriculture in the irrigation zone and the southeast of the south of the south of Kazakhstan will serve as a basis for: Monitoring of soil fertility in the development of modern technologies for cultivating crops in various crop rotations under irrigation and the Bogan; Indications and bio-diagnostics of soils; Bio-diagnostics of efficiency and ecological compatibility of agro technical and agrochemical methods of increasing soil fertility under the biological system of farming

\section{Results and Discussion}

Field experiments were laid on light chestnut soils in Almalybak village, Almaty region, Kazakhstan. Light chestnut soils are found in relief depressions with a comparatively near occurrence of groundwater $(1.5-2.0 \mathrm{~m})$. According to the granulometric composition, the described soil belongs to light loamy soils. The chemical composition of the morphological section shows that light chestnut soil is characterized by a moderate humus content (Table 1).

Table 1: Basic agrochemical indicators of light chestnut soil

\begin{tabular}{|l|l|l|l|l|l|l|}
\hline $\begin{array}{l}\text { Dept } \\
\text { h, } \\
\mathbf{c m}\end{array}$ & $\begin{array}{c}\text { Hu- } \\
\text { mus, \% }\end{array}$ & $\begin{array}{c}\text { The } \\
\text { total } \\
\text { nitro- } \\
\text { gen, \% }\end{array}$ & $\begin{array}{l}\text { C: } \\
\mathbf{N}\end{array}$ & $\begin{array}{c}\text { Gross } \\
\text { potassi- } \\
\text { um, \% }\end{array}$ & $\begin{array}{c}\text { General } \\
\text { soft- } \\
\text { ware, \% }\end{array}$ & $\begin{array}{c}\mathbf{C O}_{\mathbf{2}} \text {, } \\
\text { \% }\end{array}$ \\
\hline $\mathbf{0 - 2 4}$ & 1.78 & 0.120 & $\begin{array}{l}11 . \\
8\end{array}$ & 2.6 & 0.19 & 5.80 \\
\hline $\begin{array}{l}\mathbf{2 4 -} \\
\mathbf{3 2}\end{array}$ & 1.69 & 0.119 & $\begin{array}{l}11 . \\
9\end{array}$ & 2.1 & 0.16 & 5.84 \\
\hline $\begin{array}{l}\mathbf{3 2}- \\
\mathbf{5 9}\end{array}$ & 1.00 & 0.060 & 9.6 & 1.09 & 0.17 & 5.88 \\
\hline $\begin{array}{l}\mathbf{5 9}- \\
\mathbf{1 0 3}\end{array}$ & 0.46 & 0.039 & 6.8 & 1.1 & 0.14 & 7.30 \\
\hline
\end{tabular}

In the distribution of humus along the profile, the following regularity should be noted: a relatively high content of it in the upper horizon sharply, more than twice, falls on passing to the next subsurface horizon. Further decrease in the humus content occurs gradually, stretching to a considerable depth. The content of gross nitrogen in the soil is low and is $0.12 \%$, so that the ratio of humus carbon to total nitrogen is wide. In this case, it varies within 10-12, that is, the ratio of humus carbon to total nitrogen compared with zonal analogs is broader than in zonal soils. The total content of phosphoric acid in the humus horizon does not exceed the limits of $0.14-0.19 \%$, which characterizes the low level of security. The amount of $\mathrm{CO}_{2}$ varies from 5.80 to $7.30 \%$, with a minimum in the upper horizon and a maximum in the lower horizon. The increase in the percentage content of $\mathrm{CO}_{2}$ with increasing depth occurs gradually, which is apparently associated with hydrogen accumulation. The results of the analysis of aqueous extract (Table 2) show that the arable and sub-plowed horizons of the described soil are not saline, but at the same time a small but toxic amount of normal carbonates is present in the lower horizons, which leads to a weak alkaline soil and medium alkalinity of the soil solution.
Table 2: Data on the water extract of the soil section of light chestnut soil

\begin{tabular}{|c|c|c|c|c|c|c|}
\hline \multirow{2}{*}{$\begin{array}{c}\text { Depth, } \\
\text { cm }\end{array}$} & \multirow{2}{*}{$\begin{array}{c}\text { Dry resi- } \\
\text { due, } \%\end{array}$} & \multicolumn{4}{|c|}{ mg-eq., \% } & \multirow{2}{*}{ pH } \\
\hline & & $\mathrm{CO}_{3}{ }^{2-}$ & $\mathrm{HCO}_{3}^{-}$ & $\mathrm{Cl}^{-}$ & $\mathrm{SO}_{4}{ }^{2-}$ & \\
\hline $0-24$ & 0.164 & - & $\frac{0.9785}{0.0597}$ & $\frac{0.0789}{0.0023}$ & $\frac{0.4200}{0.0202}$ & 7.8 \\
\hline $24-32$ & 0.170 & - & $\frac{0.0510}{0.8360}$ & $\frac{0.0674}{0.0019}$ & $\frac{0.487}{0.0234}$ & 7.9 \\
\hline $32-59$ & 0.182 & $\frac{0.0037}{0.123}$ & $\frac{1.772}{0.1081}$ & $\frac{0.1171}{0.0033}$ & $\frac{0.291}{0.0140}$ & 8.1 \\
\hline $\begin{array}{l}59- \\
103\end{array}$ & 0.268 & $\frac{0.0139}{0.463}$ & $\frac{2.032}{0.1240}$ & $\frac{0.1491}{0.0042}$ & $\frac{0.291}{0.0140}$ & 8.3 \\
\hline
\end{tabular}

The dry residue in the upper horizons does not exceed $0.164 \%$. The maximum of salts is in the middle part of the profile. Such a distribution indicates the pulling of water-soluble salts from deep horizons. Of the anions, the $\mathrm{HCO}_{3}{ }^{-}$ion predominates with a low content of sulfate and chlorine ions. It should be noted that normal carbonates are found in the profile. The amount of it along the profile is distributed unevenly. In the humus horizon (0-32 $\mathrm{cm})$ they are absent, in the parent rock its content is not large, and in the middle part of the profile it is within the limits of toxicity for plants $(>0.001 \%)$. Quantitative indices of the most important physical and water-physical properties of light chestnut soils are given in Table 3. The specific mass varies within the range of 2.61-2.70 $\mathrm{g} / \mathrm{cm}^{3}$, gradually increasing with depth. The bulk mass of the upper horizons is relatively small $1.20-1.24 \mathrm{~g} / \mathrm{cm}^{3}$, a sharp increase is observed only from a meter depth. In this regard, the overall porosity of the upper horizons is relatively high $47-51 \%$. The seal begins with a layer lying deeper than $80 \mathrm{~cm}$. The agrochemical characteristics of the soils of the experimental section on which the field experiments were laid are presented in Table 4.

Table 3: Physical and hydrophysical properties of light chestnut soil

\begin{tabular}{|c|c|c|c|c|c|}
\hline $\begin{array}{c}\text { Depth } \\
\text { Cm }\end{array}$ & $\begin{array}{c}\text { Volumet- } \\
\text { ric } \\
\text { weight, } \\
\mathrm{g} / \mathrm{cm}^{3}\end{array}$ & $\begin{array}{c}\text { Specif- } \\
\text { ic } \\
\text { weight } \\
\text { g } / \mathrm{cm}^{3}\end{array}$ & $\begin{array}{c}\text { Overall } \\
\text { porosi- } \\
\text { ty, } \%\end{array}$ & $\begin{array}{c}\text { The } \\
\text { mois- } \\
\text { ture } \\
\text { capaci- } \\
\text { ty of } \\
\text { the } \\
\text { extreme } \\
\text { field, } \\
\%\end{array}$ & $\begin{array}{c}\text { Maximum } \\
\text { hygro- } \\
\text { scopic } \\
\text { moisture, } \\
\%\end{array}$ \\
\hline $0-24$ & 1.20 & 2.61 & 51 & 27.1 & 5.02 \\
\hline $24-32$ & 1.24 & 2.61 & 50 & 26.3 & 4.28 \\
\hline $32-59$ & 1.30 & 2.68 & 49 & 26.2 & 4.43 \\
\hline $\begin{array}{l}59- \\
103\end{array}$ & 1.33 & 2.70 & 47 & 22.0 & 4.41 \\
\hline
\end{tabular}

Table 4: Agrochemical properties of irrigated light chestnut soils of the experimental site

\begin{tabular}{|c|c|c|c|c|c|c|c|c|}
\hline \multirow{2}{*}{$\begin{array}{c}\text { Depth } \\
\text { cm }\end{array}$} & $\begin{array}{c}\text { Con- } \\
\text { tent } \\
\text { hu- } \\
\text { mus, } \\
\text { \% }\end{array}$ & $\begin{array}{c}\text { O } \\
\mathbf{O}_{2}\end{array}$ & \multicolumn{2}{|c|}{$\begin{array}{c}\text { Gross } \\
\text { forms, \% }\end{array}$} & $\mathbf{N}$ & $\mathbf{P}$ & \multicolumn{4}{|c|}{$\begin{array}{c}\text { Movable forms, } \\
\text { mg/kg soil }\end{array}$} & $\begin{array}{c}\mathbf{N}- \\
\mathbf{N} \\
\mathbf{O}_{\mathbf{3}}\end{array}$ & $\begin{array}{c}\mathbf{P}_{\mathbf{2}} \\
\mathbf{O}_{\mathbf{5}}\end{array}$ & $\mathbf{K}_{\mathbf{2}} \mathbf{O}$ \\
\hline $0-24$ & 1.78 & 5.9 & 0.221 & 0.19 & 87 & 25 & 26 & 435.1 \\
\hline $24-32$ & 1.69 & 5.8 & 0.172 & 0.18 & 69 & 36 & 13 & 417.2 \\
\hline
\end{tabular}

The humus content in the plow horizon is $1.78 \%$, which gradually decreases with depth. The content of total nitrogen $0.221 \%$ phosphorus average $-0.190 \%$. In terms of availability of accessible soil elements, the experimental soil areas are characterized as medium-rich easily hydrolyzed nitrogen - 87 $\mathrm{mg} / \mathrm{kg}$ and high potassium - $435.1 \mathrm{mg} / \mathrm{kg}$. According to the content of mobile phosphorus belongs to the group of poorly provided - 22-25 mg/kg soil. Thus, light chestnut soil by waterphysical properties and the level of potential fertility is quite favorable for cultivating all types of crops. It was noted that there is a clearly expressed correlation between the content of humus in the soil and the number of the soil invertebrate complex, which makes it possible to use data on the general composition of the mesofauna for characterizing this index as well. 
Table 5: Humus content and abundance of mesofauna of the main soils of vertical zonalityof the Northern Tian Shan

\begin{tabular}{|l|l|l|l|}
\hline \multirow{2}{*}{ Soil } & \multirow{2}{*}{ Humus, \% } & \multicolumn{2}{|l|}{ Number of invertebrates } \\
\cline { 3 - 4 } & & $\begin{array}{l}\text { Total spe- } \\
\text { cies }\end{array}$ & Number per $\mathbf{1 ~ m}^{\mathbf{2}}$ \\
\hline Light chestnut & $1.00-1.78$ & 4 & 16 \\
\hline
\end{tabular}

The data in Table 5 show how the humus content affects the abundance of the mesofauna of soils, while the humus content in the upper arable layers is $1.78 \%$, the mesofauna number of the soils is 16 units $/ \mathrm{m}^{2}$.Thus, we have established the dependence of the indices of biological activity (mesofauna) on the content of organic compounds in the soil. Identified species are soil invertebrate animals that are indicators of soil contamination with pesticides and high fertilizer rates. Pesticides are an environmental factor that has emerged in nature due to the widespread use by man of foreign compounds to control weeds and pests of cultivated plants. Pesticides are capable of altering the biological properties of soils, partially disturbing or leading to the complete loss of their fertility. In addition, pesticides and high doses of fertilizers also change the more conservative features of ecosystem soils, such as humus status, structure, soil $\mathrm{pH}$. In polluted soils along with microorganisms such valuable indicators of humus content and soil pH regulators, like earthworms, are lost. Light chestnut have a resistance to contamination with pesticides and, in particular, fertilizers. However, they are not always able to withstand the effects of pollutants. Our group carried out studies on the effect of contamination of investigated soils with high fertilizer doses and pesticides on representatives of soil mesofauna. On the basis of complex studies, a comparative analysis of methods for assessing the biological activity of the studied soils was carried out. The obtained data made it possible to reveal the degree of stability of light chestnut soils in the irrigation zone and the bogs of southeast Kazakhstan to contamination with pesticides and high doses of fertilizers. The species of soil invertebrates have been identified, which must be used as bioindicators to monitor the pollution of light chestnut soils with pesticides and high doses of fertilizers. The results of the research will be applied in the development of practical recommendations on the use of biological indicators as monitoring of the ecology of the soil environment and its compliance with the principles of biological farming for households that produce environmentally friendly products, as well as for agricultural control authorities. We have determined the effect of pesticides and high fertilizer doses and on the number of major groups of soil mesofauna in the system of modern agriculture in the irrigation zone and the bogs of the southeast of Kazakhstan. The activity of the mesofauna of soils were certainly affected by the degree of soil contamination with high doses of fertilizers and pesticides. For the soil, in which the content of pesticides exceeds 2 more times, pronounced changes are observed. The number of species of soil invertebrates from the family (Carabida) is decreasing, the most resistant species (Curculionidae, Scarabaidae) begin to predominate. The study of the effect of pesticides on soil invertebrates is especially important, because agricultural crops, soil animals, soil are in dark interaction. The use of pesticides causes a reduction in the number of useful soil invertebrates, can not but affect the processes occurring on the bog and irrigation.An analysis of the literature on the effect of pesticides on the mesofauna of soils shows that most of the studies have been carried out in agrobiocenoses, and, as a rule, they concern the effect of pesticides on individual groups of invertebrates. The effect of pesticides on soil fauna depends on many factors: not only on the chemical properties, the forms of application and concentration of the preparation, but also on the properties of the soil, primarily the humus content, humidity, mechanical composition, $\mathrm{pH}$, etc. in it. We have found that pesticides are low toxicity for Lumbricidae and highly toxic even in insignificant amounts for representatives of the Carabida family. The results obtained by us show that soil contamination with insignificant doses of pesticides leads to a change in the species composition of soil invertebrates. The data obtained by us confirm that there is a significant decrease in the species diversity (by $20 \%$ ) of the complex of soil invertebrate families of lamelli- formes (Scarabaidae) and an increase in the absolute dominance of such species as earthworms (Lumbricidae), ants (Formicidae). The obtained results give grounds to conclude that, unlike the abundance indices, the species composition of soil organisms can been used as a criterion for a qualitative assessment of the degree of pesticide exposure to soil. Analysis of data on the mesofauna on the investigated variants of the experiment showed that the insect larvae - Lumbricidae, Formicidae, Scarabaeida - are the dominant species. In addition to the high abundance, tangible biomass and widespread occurrence, the mesofauna was characterized by the ability to respond quickly to changes in the ecosystem, the availability of species identification and the possibility of using the quantitative characteristics associated with the availability of standard conventional isolation methods for comparison. The number of mesofauna on the bog varied from 1 to up to 20 copies / $\mathrm{m} 2$. In our opinion, one of the factors of fluctuations in population is the change of crops in the crop rotation (Table 6). After sinking in the fields, the number of lamelliformes (Scarabaeidae) and earthworms (Lumbricidae) increases. The increased number of these groups is also preserved under chick peas, placed in pairs. In the field with chickpea, the abundance of Lumbricidae decreases with a simultaneous increase in the larvae of the Carabidae family.

Table 6: Effect of processing techniques on the number of soil mesofauna (rainfed lands, light chestnut soils)

\begin{tabular}{|c|c|c|c|}
\hline \multirow{2}{*}{ Predecessor } & $\begin{array}{c}\text { Soil cultivation } \\
\text { methods }\end{array}$ & \multicolumn{2}{|c|}{ Soil invertebrates } \\
\cline { 2 - 4 } & $\begin{array}{c}\text { quantity } \\
\text { of groups }\end{array}$ & $\begin{array}{c}\text { total number } \\
\text { of inverte- } \\
\text { brates / } \mathbf{~ m}^{2}\end{array}$ \\
\hline Pure steam & $\begin{array}{c}\text { Cutting planning } \\
\text { for 20-22 cm }\end{array}$ & 2 & 8 \\
\cline { 2 - 4 } & $\begin{array}{c}\text { Cutting for 10-12 } \\
\text { cm }\end{array}$ & 4 & 16 \\
\cline { 2 - 4 } & Direct seeding & 1 & 4 \\
\hline Chick-pea & $\begin{array}{c}\text { Cutting planning } \\
\text { for 20-22 cm }\end{array}$ & 3 & 12 \\
\cline { 2 - 4 } & $\begin{array}{c}\text { Cutting for 10-12 } \\
\text { cm }\end{array}$ & 5 & 20 \\
\cline { 2 - 4 } & Direct seeding & 2 & 16 \\
\hline
\end{tabular}

From this table it can be seen that the number in different fields of crop rotation ranged from 1 to 20 invertebrates $/ \mathrm{m}^{2}$. In our opinion, one of the factors of fluctuations in numbers is the change of crops in the crop rotation. After sinking in the fields, the number of lamelliformes (Scarabaeidae) and earthworms (Lumbricidae) increases. The increased number of these groups is also preserved under chick peas, placed in pairs. Investigations of the influence of soil cultivation methods have shown that when a flat-topped plane is used, the abundance of insects rises by $12 \%$, while earthworms, on the contrary, decrease by $17 \%$. With direct sowing recommended by the system of farming in the fields studied, there is a decrease in the number of insect pests to $9 \%$. Our research has shown that the anthropogenic factor (agro-technical methods used in the cultivation of different crops, the use of fertilizers, pesticides) have a significant effect on the mesofauna of soils. When choosing organisms, the occurrence of which in the soil can be an indicator of soil conditions, the issue of food links is important, tk. this factor can be decisive in the propagation of the animal, but completely insignificant for the characterization of the soil. Analysis of the number and group composition of mesofauna in the studied soils shows that their division by type of food has not only a positive global - ecological, but also agronomic significance. On light chestnut soils, mainly larvae from the family Curculionidae, Scarabaeidae are found. 

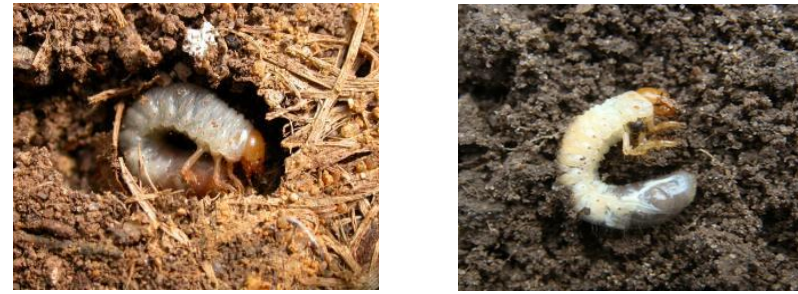

Fig 1: Larva from the family Scarabaeidae - indicator species for light chestnut soils

We also carried out a comparative analysis of the mesofauna of the studied soils according to the type of food. In the composition of soil fauna, there are three main groups according to the type of food (Gilyarov M.).

1. Phytophagous are animals that feed on underground parts of living higher plants.

2. Zoophages are animals that feed on other animals.

3. Saprophages - animals that feed on the decaying remains of living organisms, mainly plants (Table 7).

Table 7: Zoological bio-diagnostics of the investigated soils by type of nutrition

\begin{tabular}{|c|c|c|c|}
\hline \multirow[b]{2}{*}{$\begin{array}{l}\text { Type } \\
\text { of soil }\end{array}$} & \multicolumn{3}{|c|}{ Type of nutrition } \\
\hline & $\begin{array}{c}\text { Saprophagy, } \\
\text { pcs } / \mathrm{m}^{2}\end{array}$ & $\begin{array}{c}\text { Phytophagous, } \\
\text { pcs } / \mathrm{m}^{2}\end{array}$ & $\begin{array}{c}\text { Zoophagi, } \\
\text { pcs } / \mathrm{m}^{2}\end{array}$ \\
\hline 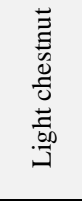 & $\begin{array}{l}\text { Earthworms } \\
\text { (Lumbricidae) } \\
-7.2 \\
\text { Kivsyaks } \\
\text { (Juliformidae) } \\
-4.0\end{array}$ & $\begin{array}{l}\text { Scarabaidae - } 6.6 \\
\text { Weevils (Curculi- } \\
\text { onidae) }-4.4 \\
\begin{array}{l}\text { Darkling } \\
\text { nebrionidae })\end{array} \text { - } 3.5 \text { - }\end{array}$ & $\begin{array}{l}\text { Ladybugs (Coc- } \\
\text { cinellidae) }-5.5 \\
\text { Ants (Formicidae) } \\
-4.2 \\
\text { Beetles (Carabidae) } \\
-4.2\end{array}$ \\
\hline
\end{tabular}

The data of Table 7 indicate that among the saprophages on the investigated soils, earthworms (Lumbricidae) and kivsyaks (Juliformidae) have been identified.

Bright representatives on the investigated soils among phytophages are lamelliformes (Scarabaidae); darkling beetles ( $T e$ nebrionidae); weevils (Curculionidae), and from zoophages representatives from the family of ladybugs (Coccinellidae); ants (Formicidae); ground beetles (Carabidae).

Classification by type of food, is of great practical importance, because it can predict a decrease in the yield of cultivated crops.

Mesofauna, along with other soil characteristics, can very well be used as a bioindicator. Biodiagnostics of the investigated soils was carried out by us according to a classification based on the trophic connection and habitat of soil invertebrates (Table 8).

Table 8: Bioindicators of the investigated soils

\begin{tabular}{|l|l|l|l|l|}
\hline $\begin{array}{l}\text { Type of } \\
\text { soil }\end{array}$ & $\begin{array}{l}\text { Kind of } \\
\text { soil }\end{array}$ & Class & Squad & Family \\
\hline $\begin{array}{l}\text { Light } \\
\text { chestnut- } \\
\text { soils }\end{array}$ & $\begin{array}{l}\text { Arthro- } \\
\text { pods... }\end{array}$ & Insects & $\begin{array}{l}\text { Coleop- } \\
\text { tera }\end{array}$ & $\begin{array}{l}\text { Curculionidae- wee- } \\
\text { vils } \\
\text { Scarabaeidae - la- } \\
\text { melliformes }\end{array}$ \\
\hline
\end{tabular}

Thus, these bioindication types of the investigated soils are present irrespective of the application of mineral fertilizers and, accordingly, the level of pesticide content. For light chestnut soils, larvae of mesofauna from the family Curculionidae, Scarabaeidae are characteristic representatives. Representatives of these families and can be used as bioindicators in conducting studies on the investigated soils.

\section{Conclusion}

It has been revealed that the soils under study differ in relatively favorable physical properties, which in turn affects the distribution of the mesofauna. When the biological activity of soils was diagnosed, a decrease in the activity of soil mesofauna was noted in variants with high doses of phosphorus fertilizers depending on the type of soil. In light chestnut soils, meso-faunistic indices are reduced to $\left(16 \mathrm{ind} / \mathrm{m}^{2}\right)$ and poor group diversity. The main representatives of the soil mesofauna are Carabidae, Formicidae,
Lumbricidae, Scarabeidae. Typical species for fertilized soils are Carabidae, Lumbricidae, Scarabeidae. It was revealed that larvae of the mesofauna of soils from the family Curculionidae, Scarabaeidae are characteristic representatives. Representatives of these families and can be used as bioindicators in conducting studies on the investigated soils. Bioindicator species of the investigated soils are present irrespective of the use of mineral fertilizers and, accordingly, the level of pesticide content.

\section{Acknowledgments}

This work was conducted under the project AP05135938 «Ecological-agrochemical assessment of soil fertility and efficiency of fertilizer application in the foothill zone of the southeast of Kazakhstan» funded by the Ministry of Education and Science of Kazakhstan.

\section{References:}

[1] Gilyarov M. Influence of soil conditions on the fauna of soil pests. Soil Science. 2014; (9): 48-77.

[2] Krivolutsky D. Morpho-ecological types of armor mites. Zool.journal. 2007; 44 (8): 1176-1189.

[3] Gilyarov MS, Striganova BR. The role of soil invertebrates in the decomposition of plant residues and the circulation of substances. The results of science, zoology of invertebrates (soil zoology) 2008 (pp.8-69).

[4] Dimo N, Gilyarov MS, Perel TS, Striganova BR, Chernova NM 2014: Proceedings of the 10th International Congress of Soil Scientists, Moscow. Nauka; 2014 May 5. 